\section{Motherhood and Personality}

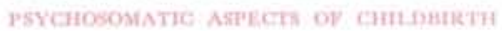

\section{LÉON CHERTOK}

Foreword by Professar Norman Morris

A clinical and experimental study of the relationship between personality factors and pain in childbirth, with an evaluation of the various psychosomatic methods of preparation.

Mind and Medicine Monographs, .No. 8 $^{8} 55$ s, net.

\section{Evolution and Human Behavior} ALEXANDER ALLAND

'Mr Alland's enthusiasm for his subject and his broad background in subjects ranging from chemical biology to cybernetics have produced a book which should attract both interested novices and advanced students.'

New York Times Book Review

Hardback 36s, net; Social Science Paperback 18 s. net.

\section{The Roots of Individuality}

NORMAI. PATTURNS OF DEVELDPMENT IN INFANCX

\section{SIBYILE}

K. ESCALONA

The product of twenty vears of intensive research by one of the world's most eminent child psychologists, this study of the early stages of human development will be a presiding influence on practice and research for many years to come.

E.5 net, August.

\section{TAVISTOCK PUBLICATIONS}

\title{
International Planned Parenthood Federation
}

Information available on all aspects of world family planning programmes

*IPP NEWS - A monthly bulletin on population problems and family planning programmes in seven languages

"IPPF Medical Bulletin-published quarterly for the medical profession on family planning and advances in contraception in five languages

*Publications include:

Film list - teaching aids - conference proceedings - fact sheets - annual reports medical handbooks - simple guides on family planning - population booklets working papers

For further information, sample copies and details of other publications (state language required):

IPPF, 18-20 Lower Regent Street, London, S.W.I 


\section{JOURNAL OF BIOSOCIAL SCIENCE}

\section{Contents}

AUdrey W. M. WARD. Family planning clinics in Sheffield, 1967 . $\quad 207$

MARIJ AvČIN. Gypsy isolates in Slovenia . . . . . . . 221

C. B. GOODHART. Estimation of illegal abortions . . . . . . . 235

JAMES MAXWELL. Intelligence, education and fertility: a comparison between the 1932 and 1947 Scottish Surveys . . . . . . . 247

Book reviews

C. O. CARTER reviews Genetics (By M. W. Strickberger) . . . . 273

M. E. J. WADSwORTH reviews Delinquency in Girls (By John Cowie, Valerie Cowie and Eliot Slater) .

M. P. M. RICHARDS reviews Genetic and Environmental Influences on Behaviour (Edited by J. M. Thoday and A. S. Parkes) . . . . . . . 281

\section{Personal and Community Factors in Fertility Control}

Proceedings of a Symposium organized by Syntex Pharmaceuticals Ltd, Brighton, 25th September 1968

Claire Russell and W. M. S. Russell. Sociological factors . . . 289

EDWIN BROOKS. Political and economic factors . . . . . . 297

M. Shirley EMERSON. Personal factors . . . . . . . . . 307

Miriam MoORe-Robinson. Future prospects . . . . . . . 315

HILARY HILl. Educational factors . . . . . . . . . . 321

The Journal of Biosocial Science is published quarterly, in January, April, July and October, forming one volume. The subscription rate for 1969 is $£ 7$ (US \$20.00) per annum, post free. The price for single issues is $37 \mathrm{~s} 6 \mathrm{~d}$ (US \$5.00). All correspondence and remittances relating to subscriptions, back numbers and reprints should be sent to the publishers: Blackwell Scientific Publications Ltd, 5 Alfred Street, Oxford OX1 4HB. Published by Blackwell Scientific Publications Ltd for the Galton Foundation. Under its Trust Deed the Foundation must apply all its resources towards the promotion of biosocial science. 